\title{
Pemodelan Analisis Rantai Markov untuk Mengestimasi Potensi Kasus Narkoba di Indonesia
}

\author{
(Markov Chains Modelling Analysis to Estimate Drug Cases in Indonesia) \\ Bagaskoro Cahyo Laksono ${ }^{1 *}$, Nucke Widowati Kusumo Projo ${ }^{2}$ \\ 1,2 Politeknik Statistika STIS \\ Jalan Otto Iskandardinata No 64C Rt.1/Rw 4, Bidara Cina, Jati Negara, Jakarta Timur 13330 \\ E-mail:211810211@stis.ac.id
}

\begin{abstract}
ABSTRAK
Penyalahgunaan narkoba tidak hanya mengancam kelangsungan hidup dan masa depan penyalahgunanya saja, namun juga masa depan bangsa dan negara. Untuk itu diperlukan informasi yang terkini mengenai keparahan penyalahgunaan narkoba, antara lain melalui pencatatan jumlah kasus narkoba. Penelitian ini bertujuan untuk menganalisis potensi kasus narkoba di enam provinsi dengan jumlah tertinggi kasus narkoba yang dilaporkan di Indonesia yaitu Sumatra Utara, Jambi, Bali, Kalimantan Tengah, Kalimantan Selatan dan Kalimantan Timur. Metodologi yang digunakan dalam penelitian ini adalah analisis deskriptif dan analisis rantai Markov. Hasil estimasi jumlah kasus narkoba dalam lima tahun yaitu dari 2019 hingga 2023 diperoleh hasil bahwa Provinsi Kalimantan Timur merupakan provinsi dengan kasus narkoba paling banyak. Kemudian diikuti Sumatra Utara, Bali, Kalimantan Selatan, Kalimantan Tengah, dan Jambi.
\end{abstract}

Kata kunci: narkoba, rantai markov, matriks transisi, steady state

\section{ABSTRACT}

Drug abuse not only threatens the survival and future of the abuser, but also the future of the nation and state. For this reason, up-to-date information is needed regarding the severity of drug abuse, including through recording the number of drug cases. This study aims to analyze the potential for drug cases in six provinces with the highest number of reported drug cases in Indonesia, namely North Sumatra, Jambi, Bali, Central Kalimantan, South Kalimantan and East Kalimantan. The methodology used in this research is descriptive analysis and Markov chain analysis. The results of the estimation of the number of drug cases in five years, from 2019 to 2023, show that East Kalimantan Province is the province with the most drug cases. Then followed by North Sumatra, Bali, South Kalimantan, Central Kalimantan, and Jambi.

Keywords: drugs, markov chain, transition matrix, steady state

\section{PENDAHULUAN}

Sekitar 275 juta orang menggunakan narkoba di seluruh dunia pada tahun 2020. Sementara itu, lebih dari 36 juta orang menderita gangguan penggunaan narkoba, seperti diungkapkan dalam World Drugs Report 2021 yang dirilis oleh Kantor PBB untuk Narkoba dan Kejahatan (UNODC, 2021). Dalam dunia medis, narkoba (narkotika dan obat-obatan) digunakan dalam proses penyembuhan. Namun mengonsumsi narkoba yang berlebihan dan disalahgunakan dapat menimbulkan efek kecanduan. Menurut UU Narkotika pasal 1 ayat 1, narkotika merupakan zat buatan ataupun yang berasal dari tanaman yang memberikan efek halusinasi, menurunnya kesadaran serta menyebabkan kecanduan. Sementara itu, diambil dari berita CNN Indonesia, Kepala Badan Narkotika Nasional, Jenderal Petrus Golose mengungkapkan bahwa peredaran narkotika mengalami peningkatan pada era pandemik COVID-19 saat ini (CNN, 2021). Tercatat pada bulan Maret 2021, terdapat barang bukti sebanyak 807,68 kilogram $(\mathrm{kg})$ sabu dalam 3 bulan terakhir. Selama 3 bulan di tahun 2021 barang yang disita sudah mencapai 70,19\% dibandingkan dengan catatan barang yang disita tahun lalu. Hal ini menandakan bahwa pandemik COVID-19 menimbulkan kebiasaan baru yang mengakibatkan efek negatif dalam perilaku masyarakat. Kegiatan dirumah saja dapat memicu kondisi stres dan salah satu wujud pelampiasannya adalah mengonsumsi narkoba.

Permasalahan narkoba di Indonesia masih merupakan suatu yang bersifat urgent dan kompleks. Dampak dari penyalahgunaan narkoba tidak hanya mengancam kelangsungan hidup dan masa depan penyalahgunanya saja, namun juga masa depan bangsa dan negara. Masalah penyalahgunaan narkoba di Indonesia sudah sangat memprihatinkan. Salah satu penyebabnya karena Indonesia yang terletak pada posisi diantara dua benua (Asia dan Australia) serta perkembangan teknologi yang semakin meningkat. Hal itu mengakibatkan proses globalisasi dan peredaran gelap narkoba semakin bebas. Maraknya peredaran gelap narkoba di segala lapisan masyarakat dapat dilihat dari angka prevalensi nasional penyalahgunaan narkoba pada tahun 2019 yaitu sebesar 2,4\% untuk pernah pakai yang berarti bahwa terdapat 240 dari 10.000 penduduk Indonesia berumur 15-64 tahun atau setara 
dengan 4,5 juta jiwa yang terpapar pernah menggunakan narkoba. Sementara terdapat 180 dari 10.000 penduduk Indonesia berumur 15 hingga 64 tahun atau sekitar 3,4 juta jiwa terpapar pernah memakai narkoba selama satu tahun terakhir.

Indonesia melakukan upaya pemberantasan kasus peredaran narkoba antara lain dengan mendirikan Badan Narkotika Nasional (BNN) pada tahun 2002 kemudian setelahnya juga membentuk badan koordinasi di level provinsi yaitu Badan Narkotika Nasional Provinsi (BNNP). Badan ini dibentuk untuk mengorganisasikan kegiatan pencegahan, pemberantasan penyalahgunaan dan peredaran gelap narkoba di Indonesia. Namun masih terdapat kesulitan dan fakta di lapangan untuk mendapatkan data sebaran kasus narkoba per provinsi di Indonesia sehingga tidak ditemukan data yang lengkap dan up to date mulai dari tahun 2019 hingga sekarang. Berdasarkan BNN (2018), secara kumulatif tercatat terdapat 5737 kasus narkoba yang dilaporkan. Angka tersebut menunjukkan bahwa pengguna narkoba di Indonesia yang terbilang tidak sedikit. Keterbaruan data yang tersedia akan membantu proses pengawasan kegiatan pemberantasan penyalahgunaan narkoba di Indonesia

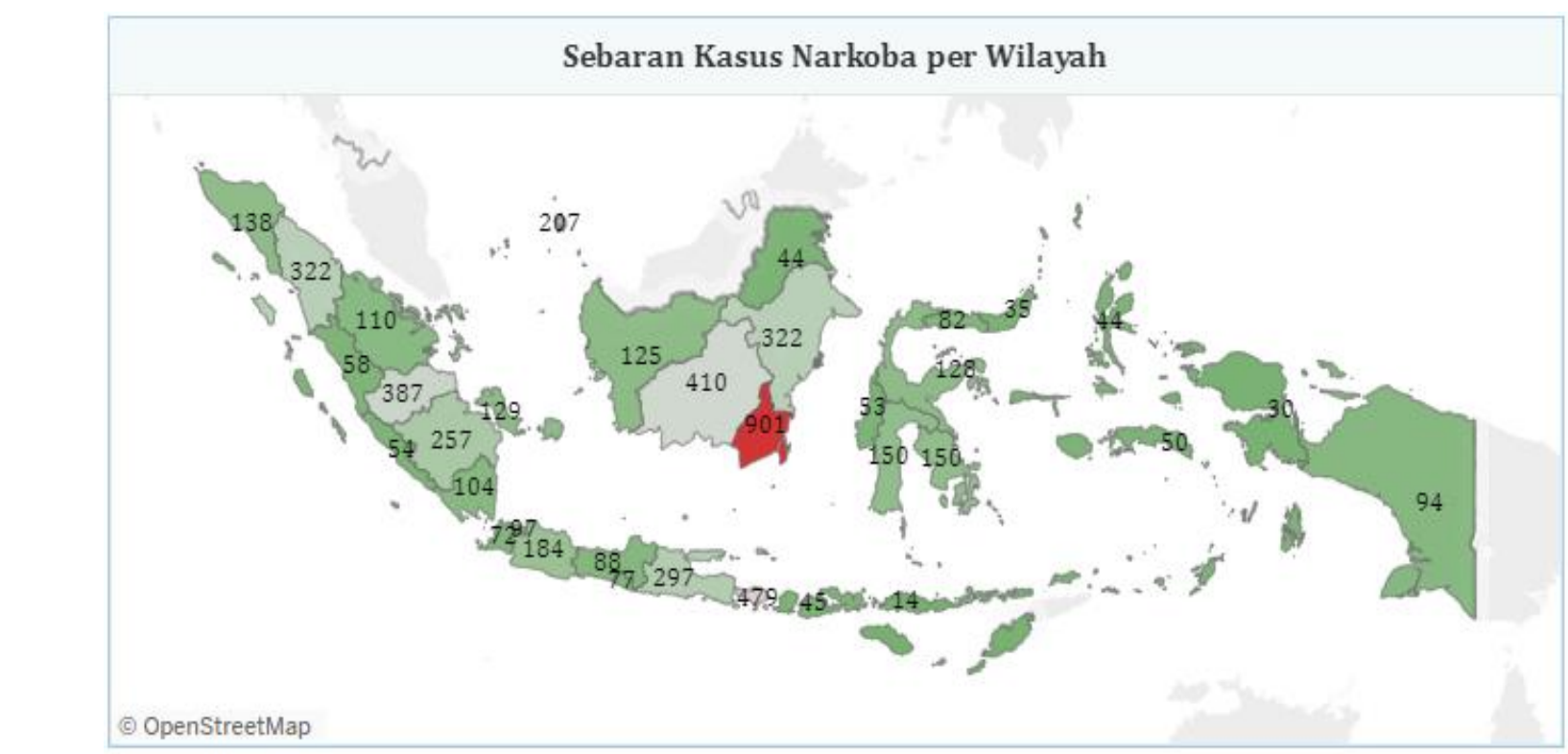

Sumber : https://puslitdatin.bnn.go.id/

Gambar 1. Sebaran Kasus Narkoba Berdasarkan Provinsi di Indonesia Tahun 2018

Berdasarkan sebaran pada Gambar 1 dapat ditampilkan enam urutan provinsi dengan jumlah kumulatif kasus narkoba yang dilaporkan terbanyak sejak tahun 2011 hingga tahun 2018 sebagai berikut:

Tabel 1. Provinsi Dengan Kasus Narkoba Terparah

\begin{tabular}{ccc}
\hline Kode & Provinsi & Jumlah Kasus Narkoba \\
\hline 12 & Kalimantan Selatan & 901 \\
15 & Bali & 479 \\
51 & Kalimantan Tengah & 410 \\
62 & Jambi & 387 \\
63 & Sumatera Utara & 322 \\
64 & Kalimantan Timur & 322 \\
\hline
\end{tabular}

Sumber : https://puslitdatin.bnn.go.id/

Berdasarkan Tabel 1 di atas dapat dilihat bahwa enam provinsi yaitu Kalimantan Selatan, Bali, Kalimantan Tengah, Jambi, Sumatera Utara, dan Kalimantan Timur adalah provinsi-provinsi yang paling banyak transaksi narkoba secara kumulatif dari tahun 2011 hingga tahun 2018 diantara provinsi lainnya di Indonesia. Data tersebut menunjukkan fenomena bahwa Provinsi Kalimantan Selatan memiliki jumlah kasus narkoba sangat tinggi, dibandingkan dengan provinsi yang lain.

Disamping itu, fenomena kasus narkoba mirip dengan kasus bencana alam dimana kejadiannya pasti akan terjadi di tempat yang sama dari waktu ke waktu karena dapat diasumsikan siklus pengedaran dan konsumennya berada ditempat yang sama (Puri, 2016). Banyak kasus pada periode waktu kedepan akan dipengaruhi oleh banyak kasus yang terjadi diperiode sebelumnya. Sehingga dapat diindikasikan kasus kedepannya dapat bertambah banyak apabila tidak dilakukan upaya penanganan dan pencegahan. 
Seperti studi yang dilakukan oleh Caulkins dkk. (2018), sejarah masa lalu penggunaan narkoba akan mempengaruhi distribusi peluang dari konsumsi narkoba di masa depan. Penelitian tersebut menggunakan data kasus narkoba dari tahun 1972 hingga 2000, dan diperoleh hasil bahwa terdapat keterkaitan data terhadap waktu. Dengan kondisi semacam itu, salah satu analisis yang dapat digunakan untuk menjelaskan fenomena kasus narkoba adalah analisis rantai markov. Dalam penelitian yang dilakukan oleh Everingham dan Rydell (1994), analisis rantai markov digunakan untuk memprediksi cocaine endemic akan menghilang sendiri apabila tidak di pengaruhi oleh penanganan lain.

Oleh karena itu, penelitian ini bertujuan untuk memberikan gambaran umum jumlah kasus narkoba di Indonesia, mengestimasi jumlah kasus narkoba selama lima tahun mendatang di enam provinsi terbanyak jumlah kasus narkoba, dan menganalisis tingkat keparahan kasus narkoba di enam provinsi tersebut di masa mendatang. Penulis akan membahas estimasi kasus narkoba yang akan terjadi di 6 provinsi tersebut pada tahun-tahun berikutnya (selama 5 tahun kedepan) dengan harapan hasilnya dapat digunakan BNN maupun lembaga pemerintah lainnya, terutama di provinsi-provinsi yang memiliki jumlah kasus narkoba terbanyak agar dapat mengoptimalkan upaya penanganan dan pencegahan untuk mengurangi angka kasus narkoba di masa depan. Analisis statistik yang diaplikasikan dalam penelitian ini adalah analisis Rantai Markov.

Rantai markov dapat diaplikasikan dalam berbagai bidang penelitian. Dalam studi kebencanaan untuk memprediksi kejadian bencana alam yang dilakukan oleh Fathurrahmi dkk. (2016), rantai Markov digunakan untuk mengetahui potensi bencana yang dibedakan menurut jenis dan waktu kejadian di Provinsi Jawa Tengah. Dalam bidang ekonomi, seperti studi yang dilakukan oleh Octaviani dkk. (2018) untuk melakukan optimasi penjadwalan produksi dan perencanaan persediaan bahan di perusahaan penyedia makanan. Analisis rantai markov juga digunakan untuk memprediksi perpindahan konsumen maskapai penerbangan rute Manado-Jakarta dalam penelitian Masuku, dkk. (2018). Dalam penelitian yang lebih baru, rantai Markov digunakan untuk menghitung penambapahan pasien Covid-19 di Indonesia (Aritonang dkk, 2020), memprediksi status pasien COVID-19 (Putri dkk., 2021), dan analisis perpindahan penggunaan merk Handphone di kalangan mahasiswa (Nurhamidin dkk., 2021).

\section{METODE}

\section{Metode Analisis}

Rantai Markov (Markov Chains) adalah suatu teknik matematika yang biasa digunakan untuk melakukan pemodelan (modelling) berbagai sistem dan proses bisnis. Teknik ini dapat digunakan untuk memperkirakan perubahan-perubahan di waktu yang akan datang dalam variabel-variabel dinamis atas dasar perubahanperubahan dari variabel-variabel dinamis tersebut di waktu yang lalu. Teknik ini dapat digunakan untuk menganalisis kejadian-kejadian di waktu mendatang secara matematis (Dwijanto 20008:87). Dalam menganalisis data, penulis menggunakan perangkat lunak yaitu Microsoft Excel dan Matlab.

Analisis Rantai Markov adalah suatu metode yang mempelajari sifat-sifat suatu variabel pada masa sekarang yang didasarkan pada sifat-sifatnya di masa lalu dalam usaha menaksir sifat-sifat variabel tersebut di masa yang akan datang. Rantai Markov adalah suatu deret peubah acak $X^{(0)}, X^{(1)}, X^{(2)}, \ldots, X^{(n)}$ di mana pengaruh nilai-nilai $X^{(0)}, X^{(1)}, X^{(2)}, \ldots, X^{(n)}$ kepada distribusi $X^{(n+1)}$ diperantarai secara menyeluruh oleh nilai $X^{(n)}$ (Neal, 1993).

Model Rantai Markov dikembangkan oleh seorang ahli Rusia A.A. Markov pada tahun 1896. Dalam Analisis Markov, dihasilkan suatu informasi probabilistik yang dapat digunakan untuk membantu pembuatan keputusan. Sifat dari proses stokastik dari analisis Markov adalah apabila diketahui proses berada dalam suatu keadaan tertentu, peluang berkembangnya proses di masa mendatang hanya bergantung pada keadaan saat ini dan tidak bergantung pada keadaan sebelumnya.

\section{Alur Penelitian}

Adapun langkah-langkah yang digunakan dalam penelitian ini adalah sebagai berikut:

a. Melakukan pengambilan data sekunder.

b. Menghitung jumlah kasus narkoba untuk masing-masing provinsi periode 2013-2018.

c. Menghitung peluang atau persentase masing-masing bencana setiap tahun.

d. Mengalikan matriks state bencana dengan matriks data kasus narkoba.

3. Data dan Sumber Data 
Data diambil dari Badan Narkotika National yang diakses melalui website resmi Pusat Pelatihan Data dan Informasi BNN. Data yang digunakan dalam penelitian ini adalah data populasi kasus narkoba di 6 provinsi yaitu Kalimantan Selatan, Bali, Kalimantan Tengah, Jambi, Sumatra Utara dan Kalimantan Timur yang merupakan provinsi dengan angka kasus narkoba terparah di Indonesia. Masing-masing provinsi tersebut diambil datanya pada periode 2013-2018.

\section{HASIL DAN PEMBAHASAN}

\section{Analisis Deskriptif}

Provinsi Sumatra Utara adalah salah satu provinsi yang termasuk dalam enam provinsi dengan jumlah kasus narkoba terbanyak di Indonesia. Ketika dilihat dari angka prevalensi penyalahgunaan narkoba pada tahun 2019, provinsi tersebut menempati posisi tertinggi yaitu sebesar 6,5 persen, atau setara dengan 14,6 ribu penduduk yang pernah memakai narkoba. Sementara Kalimantan Timur yang memiliki jumlah kasus narkoba terbanyak di Indonesia, angka prevalensi penyalahgunaan narkobanya tidak termasuk dalam lima provinsi dengan angka prevalensi penyalahgunaan narkoba tertinggi di Indonesia (Tabel 2). Hal ini merupakan indikasi bahwa banyaknya jumlah kasus narkoba tidak serta merta dapat dikaitkan dengan banyaknya jumlah penduduk yang melakukan penyalahgunaan narkoba. Hal ini dapat pula mengindikasikan bahwa provinsi tersebut merupakan jalur distribusi narkoba. Seperti kita ketahui bahwa provinsi Kalimantan Timur memiliki letak yang strategis dan berpotensi menjadi jalur distribusi narkoba karena berbatasan dengan Malaysia dan Provinsi Kalimantan Utara, Kalimantan Tengah, Kalimantan Selatan, Kalimantan Barat, dan Pulau Sulawesi.

Tabel 2. Angka Prevalensi Penyalahgunaan Narkoba Tertinggi

\begin{tabular}{ccc}
\hline Provinsi & Angka Prevalensi Penyalahgunaan Narkoba & Jumlah Penduduk (Ribu) \\
\hline Sumatra Utara & $6,5 \%$ & 14.639 \\
Sumatra Selatan & $5 \%$ & 8.497 \\
DKI Jakarta & $3,3 \%$ & 10.504 \\
DI Yogyakarta & $2,3 \%$ & 3.869 \\
Sulawesi Tengah & $2,8 \%$ & 3.042 \\
\hline
\end{tabular}

Sumber: Indonesia Drugs Report 2020 dan Badan Pusat Statistik

Jika dibandingkan dengan jumlah titik lokasi kawasan narkoba di Indonesia yang ditampilkan dalam Tabel 3, Provinsi Sumatera Utara selain termasuk dalam provinsi yang memiliki jumlah kasus narkoba tertinggi, juga memiliki jumlah titik rawan yang termasuk lima tertinggi di Indonesia. Titik lokasi kawasan rawan narkoba merupakan kawasan yang dihuni penduduk yang memiliki potensi tinggi terjadinya penyalahgunaan narkoba. Hal ini merupakan indikasi bahwa jumlah kasus narkoba berkaitan dengan jumlah titik lokasi kawasan rawan narkoba.

Tabel 3. Titik Lokasi Kawasan Rawan Narkoba Tertinggi

\begin{tabular}{cc}
\hline Provinsi & Banyaknya Titik Rawan \\
\hline DKI Jakarta & 117 \\
Aceh & 64 \\
Sumatra Utara & 59 \\
Jawa Barat & 33 \\
Jawa Timur & 33 \\
\hline
\end{tabular}

Sumber: Indonesia Drugs Report 2020

Tabel 4 merupakan data jumlah kasus narkoba yang dilaporkan dari tahun 2013 hingga 2018 di enam provinsi terbanyak jumlah kasus narkoba di Indonesia. Dapat dilihat bahwa jumlah kasus narkoba di Kalimantan Selatan pada tahun 2013 adalah sebanyak nol kasus. Hal ini bukan berarti wilayah tersebut bebas dari penyalahgunaan narkoba, hanya saja pada tahun tersebut tidak ada kasus narkoba yang dilaporkan. Dari Tabel 4, diketahui jumlah total kasus dari enam provinsi dari tahun 2013 hingga tahun 2018 adalah sebanyak 2.815 kasus. Sehingga ratarata jumlah kasus narkoba per tahun di masing-masing provinsi adalah sebanyak 469 kasus. 
Tabel 4. Jumlah Kasus Narkoba Tahun 2013-2018

\begin{tabular}{cccccccc}
\hline Tahun|Provinsi & $\begin{array}{c}\text { Kalimantan } \\
\text { Selatan }\end{array}$ & Bali & $\begin{array}{c}\text { Kalimantan } \\
\text { Tengah }\end{array}$ & Jambi & $\begin{array}{c}\text { Sumatra } \\
\text { Utara }\end{array}$ & $\begin{array}{c}\text { Kalimantan } \\
\text { Timur }\end{array}$ & Jumlah \\
\hline 2013 & 0 & 289 & 240 & 315 & 766 & 18 & 1628 \\
2014 & 1 & 15 & 71 & 4 & 16 & 32 & 139 \\
2015 & 35 & 18 & 29 & 16 & 20 & 59 & 177 \\
2016 & 99 & 17 & 44 & 16 & 16 & 62 & 254 \\
2017 & 95 & 22 & 45 & 28 & 43 & 78 & 311 \\
2018 & 92 & 24 & 50 & 30 & 38 & 72 & 306 \\
\hline
\end{tabular}

Sumber: https://puslitdatin.bnn.go.id/

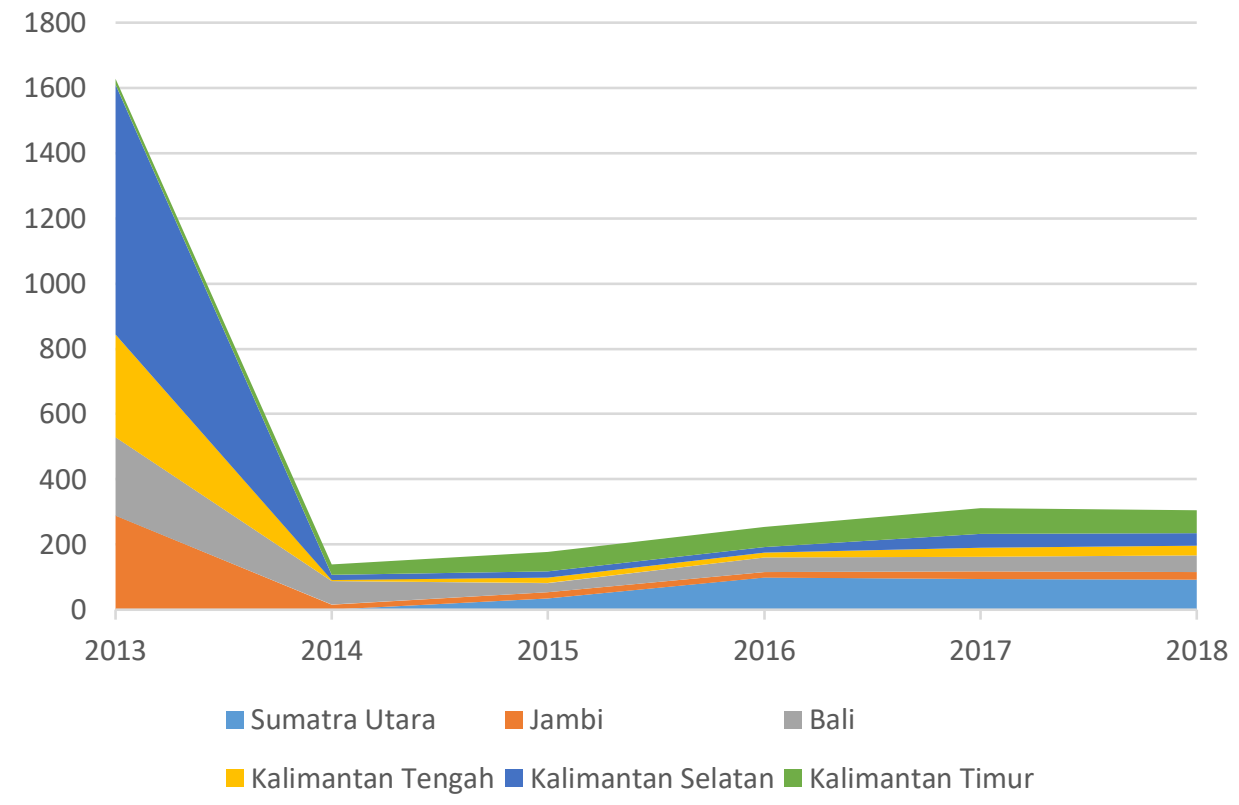

Gambar 2. Jumlah Kasus Narkoba pada Tahun 2013-2018

Data dari Tabel 4 kemudian dibuat ke dalam bentuk grafik di Gambar 2 untuk mempermudah melihat pola datanya. Berdasarkan visualisasi pada Gambar 2, dapat dilihat bahwa lonjakan kasus terjadi pada tahun 2013. Kemudian di tahun berikutnya menurun secara signifikan dan terdapat trend yang kenaikannya masih wajar.

\section{Matriks Peluang Transisi}

Matriks peluang transisi adalah hasil persentase dari kejadian tertentu dari total kejadian yang disusun kedalam bentuk matriks bujur sangkar. Matriks transisi menggunakan data kasus narkoba 2013-2018 dalam penyusunannya. Sehingga matriks transisi dalam analisis markov yang dilakukan telah mencakup informasi kasus narkoba tahun-tahun sebelumnya.

Tabel 5. Peluang Kejadian Masing-Masing Tahun

\begin{tabular}{ccccccccc}
\hline Tahun\Provinsi & $\begin{array}{c}\text { Kalimantan } \\
\text { Selatan }\end{array}$ & Bali & $\begin{array}{c}\text { Kalimantan } \\
\text { Tengah }\end{array}$ & Jambi & $\begin{array}{c}\text { Sumatra } \\
\text { Utara }\end{array}$ & $\begin{array}{c}\text { Kalimantan } \\
\text { Timur }\end{array}$ & Jumlah \\
\hline 2013 & 0 & 0,17751 & 0,14742 & 0,19348 & 0,47051 & 0,011057 & 1 \\
2014 & 0,007194 & 0,10791 & 0,510791 & 0,02877 & 0,11510 & 0,230216 & 1 \\
2015 & 0,19774 & 0,10169 & 0,163842 & 0,09039 & 0,11299 & 0,333333 & 1 & 1 \\
2016 & 0,389764 & 0,06692 & 0,173228 & 0,06299 & 0,06299 & 0,244094 & 1 \\
2017 & 0,305466 & 0,07074 & 0,144695 & 0,09003 & 0,13826 & 0,250804 & 1 \\
2018 & 0,300654 & 0,07843 & 0,163399 & 0,09803 & 0,12418 & 0,235294 & 1 \\
\hline
\end{tabular}


Berdasarkan tabel diatas, dapat dibentuk matriks peluang transisi sebagai berikut:

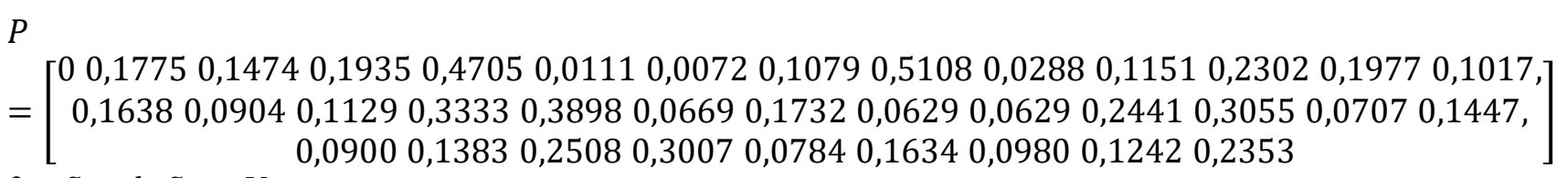

3. Steady State Vector

Steady state vector adalah vektor yang jika dikalikan dengan matriks peluang transisinya akan menghasilkan vektor itu sendiri, atau bisa dikatakan bahwa steady state merupakan suatu keadaan yang menunjukkan bahwa peluang kejadian akan tetap untuk waktu lama.

Misalkan $\mathbf{v}=\left[\begin{array}{llll}a & b & c & d\end{array}\right.$ e $\left.f\right]$ sebagai steady state vector

Untuk mencari v, dilakukan dengan menggunakan persamaan P.v $=\mathbf{v}$. Dengan pengolahan data menggunakan software matlab, didapatkan

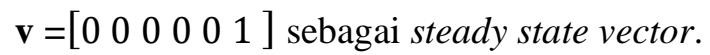

4. Menghitung Estimasi Kasus Narkoba Hingga 5 Tahun Kedepan (2019-2023)

State adalah transpose dari steady state vector itu sendiri dan dapat simbolkan dengan $\pi(0)$.

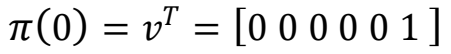

Kemungkinan kejadian kasus narkoba di tahun 2019 dapat dihitung dengan cara berikut:

$$
\begin{aligned}
& =\left[\begin{array}{llllll}
0 & 0 & 0 & 0 & 0 & 1
\end{array}\right]
\end{aligned}
$$

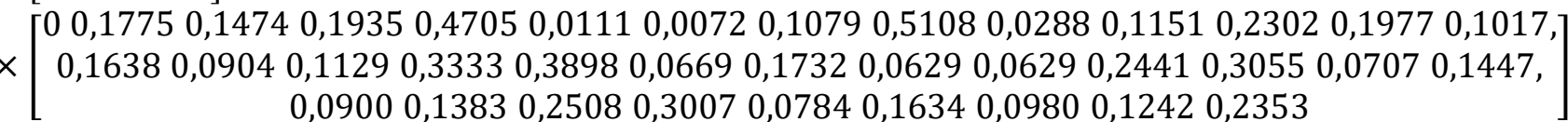

$$
\begin{aligned}
& \pi(1)=\pi(0) P \\
& =\left[\begin{array}{llllll}
0,3007 & 0,0784 & 0,1634 & 0,098 & 0,1242 & 0,2353
\end{array}\right]
\end{aligned}
$$

Untuk membuat probabilitas menjadi persentase, hasil dari $\pi(1)$ dikalikan dengan $100 \%$.

$$
\pi(1) \times 100 \%
$$

$$
=[30,07 \% \text { 7,84\% 16,34\% 9,8\% 12,42\% 23,53\% ] }
$$

Jadi kemungkinan terjadinya kasus narkoba di enam provinsi yang memiliki jumlah kasus narkoba tertinggi pada tahun 2019 dapat disusun dalam tabel seperti berikut:

Tabel 6. Presentase dan Perkiraan Kasus Narkoba Tahun 2019

\begin{tabular}{cccc}
\hline Kode & Keterangan & $\begin{array}{c}\text { Presentase dari total kejadian yang } \\
\text { akan datang }\end{array}$ & $\begin{array}{c}\text { Perkiraan (Presentase x Rata-rata } \\
\text { Kejadian (469)) }\end{array}$ \\
\hline 12 & Sumatra Utara & $30,07 \%$ & 141 \\
15 & Jambi & $7,84 \%$ & 37 \\
51 & Bali & $16,34 \%$ & 77 \\
62 & Kalimantan Tengah & $9,8 \%$ & 46 \\
63 & Kalimantan Selatan & $12,42 \%$ & 58 \\
64 & Kalimantan Timur & $23,53 \%$ & 110 \\
\hline
\end{tabular}

Untuk mengestimasi kasus narkoba tahun-tahun berikutnya dapat dihitung dengan formula sebagai berikut:

Peluang Kejadian $2020 \rightarrow \pi(0) P^{2}=[19,98 \% 11,23 \%$ 18,45\% 11,56\% 22,15\% 18,63\% ]

Peluang Kejadian $2021 \rightarrow \pi(0) P^{3}=[20.60 \% 10,08 \% 19,65 \% 10,02 \% 17,94 \%$ 21,69\% $]$

Peluang Kejadian $2022 \rightarrow \pi(0) P^{4}=[19,87 \%$ 10,39\% 19,28\% 10,43\% 18,88\% 21,15\% ]

Peluang Kejadian $2021 \rightarrow \pi(0) P^{5}=[20,08 \%$ 10,30\% 19,38\% 10,32\% 18,62\% 21,29\% ]

Kemudian hasil di atas dapat digunakan untuk menghitung presentase dan perkiraan kejadian kasus narkoba masing-masing tahunnya. Dengan cara yang sama dengan penghitungan tahun 2019, dapat diperoleh 
Tabel 7. Perkiraan Kasus Narkoba Tahun 2020-2023

\begin{tabular}{cccccc}
\hline Kode & Keterangan & \multicolumn{4}{c}{ Perkiraan Kasus Narkoba } \\
\cline { 3 - 6 } & & 2020 & 2021 & 2022 & 2023 \\
\hline 12 & Sumatra Utara & 84 & 87 & 93 & 48 \\
15 & Jambi & 53 & 47 & 49 & 91 \\
51 & Bali & 87 & 92 & 90 & 48 \\
62 & Kalimantan Tengah & 54 & 47 & 49 & 87 \\
63 & Kalimantan Selatan & 104 & 84 & 89 & 100 \\
64 & Kalimantan Timur & 87 & 102 & 99 & \\
\hline
\end{tabular}

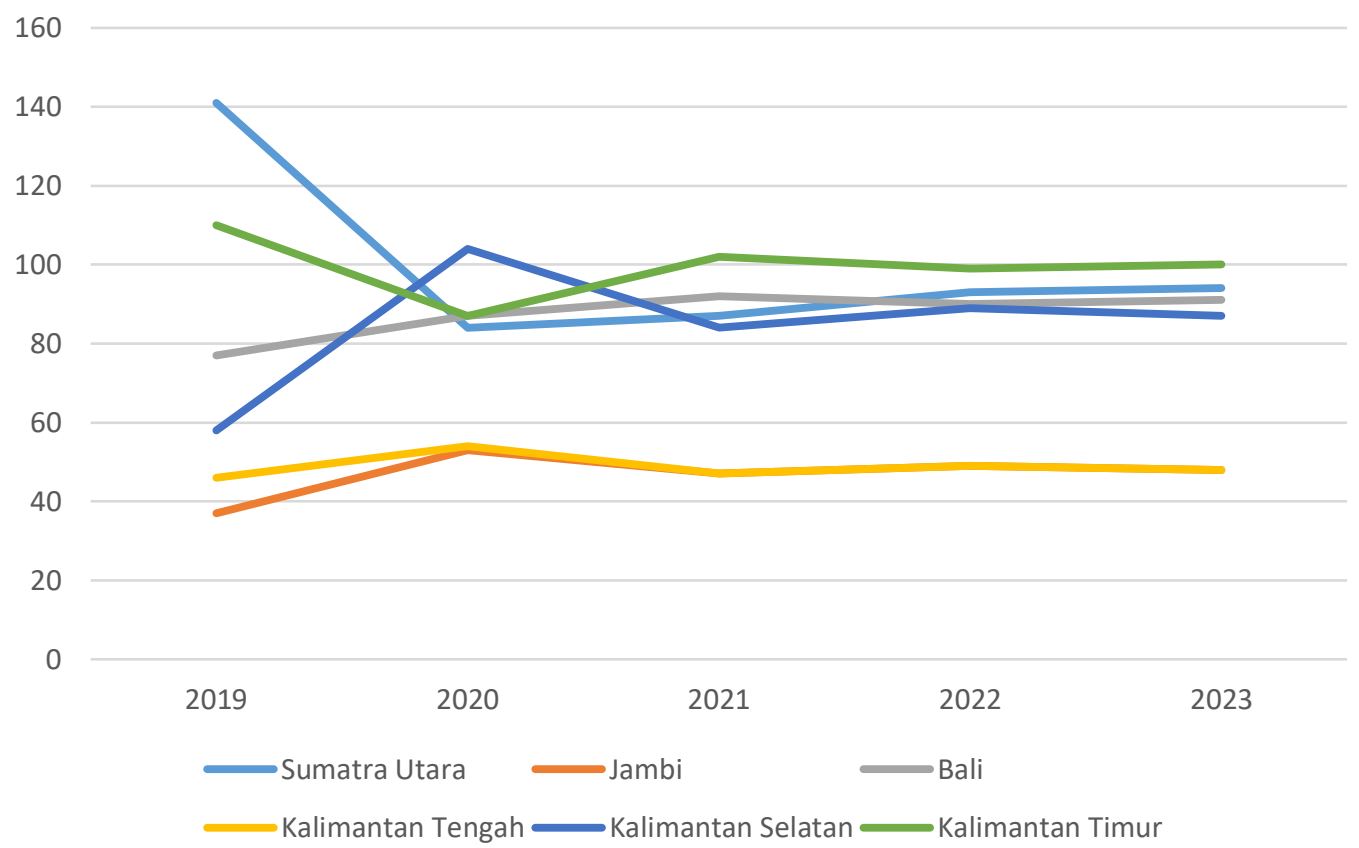

Gambar 3 Estimasi Jumlah Terjadinya Kasus Narkoba 2019-2023

Hasil estimasi jumlah kasus narkoba di enam provinsi dari tahun 2019 hingga tahun 2023 dapat memberikan gambaran mengenai keparahan penyalahgunaan narkoba di wilayah tersebut. Berdasarkan visualisasi pada Gambar 3, dapat diidentifikasikan bahwa ditahun-tahun berikutnya, Provinsi Kalimantan Timur menjadi provinsi paling parah karena memiliki angka kasus yang paling tinggi, yaitu sebesar 110, 87, 102, 99, dan 102 kasus pada tahun 2019 hingga 2023. Kemudian provinsi dengan tingkat keparahan kedua tertinggi adalah Sumatra Utara, diikuti Bali, Kalimantan Selatan, Kalimantan Tengah, dan Jambi di urutan berikutnya. Hasil estimasi jumlah kasus yang dilakukan telah memberikan hasil estimasi seperti yang diharapkan seperti juga analisis ranti Markov yang dilakukan pada studi terdahulu oleh Octaviani dkk. (2018, Fathurrahmi dkk. (2016), Masuku dkk. (2018), Aritonang dkk. (2020), Putri dkk. (2021) dan Nurhamidin dkk. (2021), meskipun dilakukan pada bidang yang berbeda-beda.

Hasil penghitungan estimasi jumlah kasus narkoba dalam penelitian ini menggunakan asumsi yang sangat kuat bahwa kondisi di keenam provinsi tersebut adalah sama atau pada kondisi tetap. Dalam artian tidak ada tindakan intervensi yang dilakukan terkait dengan kejahatan narkoba di keenam wilayah tersebut. Hal ini merupakan salah satu faktor penting yang menjadi catatan dalam intepretasi hasil estimasi. Seperti dalam penelitian Putri dkk. (2021) yang menyebutkan bahwa hasil estimasi status pasien COVID-19 menggunakan rantai Markov menjadi kurang tepat karena metode ini tidak mempertimbangkan adanya tindakan-tindakan intervensi, misalnya pada kasus penekanan laju COVID-19 adalah pembatasan kegiatan seperti Pembatasan Sosial Berskala Besar (PSBB) dan Pemberlakuan Pembatasan Kegiatan Masyarakat (PPKM) serta pemberlakuan adaptasi kegiatan baru lainnya. Perlu diketahui pula bahwa kegiatan pencegahan penyalahgunaan narkoba dalam rangka menekan jumlah kasus narkoba ini juga marak digalakkan terutama dimotori oleh BNN dan BNNP seperti kegiatan pemberdayaan masyarakat dan sosialisasi bahaya narkoba ke kalangan usia produktif seperti pelajar dan pekerja. 


\section{KESIMPULAN}

Dari enam provinsi yaitu Provinsi Kalimantan Timur, Sumatera Utara, Bali, Kalimantan Selatan, Kalimantan Tengah, dan Jambi, jumlah kasus narkoba yang dilaporkan memiliki jumlah tertinggi pada tahun 2013 dengan total kejadian sebanyak 1628. Kemudian di tahun berikutnya menurun secara drastis dan kemudian diikuti dengan kenaikan yang masih wajar.

Berdasarkan hasil perhitungan dengan konsep Markov Chains, diperoleh nilai perkiraan kasus narkoba pada tahun 2023 Sumatra Utara dengan 94 kasus, Jambi dengan 48 kasus, Bali dengan 91 kasus, Kalimantan Tengah dengan 48 Kasus, Kalimantan Selatan dengan 87 kasus dan Kalimantan Timur dengan 100 kasus.

Berdasarkan visualisasi pergerakan data untuk beberapa tahun kedepan berikutnya Kalimantan Timur menjadi provinsi paling parah karena memiliki angka kasus yang paling tinggi. Kemudian provinsi dengan tingkat keparahan kedua tertinggi adalah Sumatra Utara. Kemudian diikuti Bali, Kalimantan Selatan, Kalimantan Tengah, dan Jambi diurutan berikutnya.

Hasil penelitian ini dapat digunakan oleh BNN dan pemerintah provinsi terkait supaya dapat mengevaluasi dan melakukan perbaikan pada kegiatan-kegiatan yang berfokus pada pengurangan jumlah transaksi narkoba. Penurunan jumlah transaksi narkoba dapat menekan sisi permintaan sehingga menyebabkan kasus penyalahgunaan narkoba di Indonesia akan mengalami penurunan. Penelitian berikutnya dapat menganalisis permasalahan penyalahgunaan narkoba dengan variabel penelitian dan metode analisis yang mengakomodir adanya tindakan-tindakan intervensi lainnya.

\section{DAFTAR PUSTAKA}

Aritonang, Kinley, dkk. (2020). Analisis Penambahan Pasien COVID-19 di Indonesia Menggunakan Metode Rantai Markov. Jurnal Rekayasi Sistem Industri Volume 9 No 2-Juli 2020.

Caulkins, Jonathan P, dkk (2004). Markov Chain Modeling of Initiation and Demand: The Case of the US Cocaine Epidemic. Health Care Management Science 7, 319-329, 2004.

Everingham, Susan S dan Rydell, C. Peter. (1994). Modeling the Demand for Cocaine. Santa Monica: RAND.

Puslitdatin BNN. (2020). Indonesia 2020 Drugs Report. Pusat Penelitian, Data dan Informasi. Badan Narkotika Nasional.

BNN. (2018, Desember 31). Diakses pada 16 Mei, 2021 dari https://puslitdatin.bnn.go.id/portfolio/data-statistikkasus-narkoba/

CNN. (2021, Maret 19). Diakses pada Agustus 1, 2021 dari artikel ilmiah: https://www.cnnindonesia.com/nasional/20210319005109-12-619410/bnn-duga-penggunaan-narkoba-dirumah-meningkat-saat-pandemi

Dwijanto.2008. Riset Operasi. Unnes: Semarang

Fathurrahmi, Putri dan Jatipaningrum, M Titah. (2016). Konsep Markov Chains untuk Menyelesaikan Prediksi Bencana Alam di Wilayah Indonesia (Studi Kasus Provinsi Jawa Tengah)

Masuku, Fatimah N, dkk. (2018). Analisis Rantai Markov Untuk Memprediksi Perpindahan Konsumen Maskapai Penerbangan Rute Manado-Jakarta. Jurnal Ilmiah sains Vol. 18 No 2.-Oktober 2018.

Neal, Radford M. 1993. Probabilistic Inference Using Markov Chain Monte Carlo Methods. Toronto.

Nurhamidin, Fauziyah dan Hamin, Nurmina. (2021). Analisis Perpindahan Penggunaan Merek Handphone Dikalangan Mahasiswa dengan Rantai Markov (Studi Kasus Pada Mahasiswa UMMU Ternate Tahun 2017). Jurnal BIOSAINTEK, Vol. 3 No 1, 20-31

Octaviani, dkk. (2018). Optimasi Penjadwalan Produksi Dan Perencanaan Persediaan Bahan Baku Menggunakan Rantai Markov (Studi Kasus Kinken Cake \& Bakery Kutoarjo). Unnes Journal of Mathematics.

Putri, Nabila N dan Muliawati, Triyada. (2021). Analisis Rantai Markov dalam Memprediksi Status Pasien COVID-19 di Indonesia. Indonesian Journal of Applied Mathematics Vol. 1 (2), 2021, pp. 44-50

RI (Republik Indonesia). (2009). Undang-Undang Nomor 35 Tahun 2009 tentang Narkotika. Sekretariat Negara. Jakarta.

Ross S.M. 1996. Stochastic Processes, 2nd ed. Canada : John Wiley \& Sons

UNODC. (2021). World Drug Report 2021. United Nations : Office on Drug and Crime. 